\title{
Effect of Phonetic Association on Learning Vocabulary in Foreign Language
}

\author{
Ebubekir Bozavl1 ${ }^{1}$ \\ ${ }^{1}$ Assistant Professor, Department of Foreign Language Teaching, Atatürk University, Turkey \\ Correspondence: Ebubekir Bozavl1, Assistant Professor, Department of Foreign Language Teaching, Atatürk \\ University, Turkey.
}

Received: November 8, 2016

Accepted: December 5, 2016 Online Published: December 7, 2016

doi:10.11114/jets.v5i1.1968

URL: http://dx.doi.org/10.11114/jets.v5i1.1968

\begin{abstract}
Word is one of the most important components of a natural language. Speech is meaningful because of the meanings of words. Vocabulary acquired in one's mother tongue is learned consciously in a foreign language in non-native settings. Learning vocabulary in a system based on grammar is generally neglected or learned in conventional ways. This study is to determine the efficiency of teaching vocabulary from learning speed and retention perspective through means of phonetic association, whose examples are seldom seen in educational institutions. The study's sample consists of Turkish 5th graders at three junior high school who have just begun to learn English. Sixty-six students, 37 girls and 29 boys from three socio-economically normal state schools. Thirty three students formed the experimental group while the other 33 students constituted the control group in the empirical study. "A phonetic association vocabulary test" consisting of 25 English words, mostly verbs and nouns, was designed. This test containing English words, their pronunciation and homophonous Turkish words was administered to the experimental group, knowing that vocabulary is taught by means of phonetic association. The control group was unaware of the method, and received the conventional teaching method. The control group was given a test containing only English words. The data obtained were decrypted by descriptive and content analysis. The study's results revealed that words were learned faster and learning was retentive by the phonetic association method. In particular, recall of the words learned differentiates this method from conventional vocabulary learning methods.
\end{abstract}

Keywords: association, word, teaching, memory, sound, meaning

\section{Introduction}

Learning is an ability that begins at birth and continues until death and which separates individual from other livings in terms of consciousness, as in language competency. Learning in man takes place consciously while it is instinctive in other things. It provides man with information on certain topics and affects system of values and beliefs (Özer, 2005). Learning is not only a verbal communication, but also acquisition of such knowledge and behavior as habits, skills, attitudes and awareness (Terry, 2007). Giordan (1998) defined learning as individual or social dynamism of activation and assimilation rather than definitions based on mere information. He emphasized that the brain is an obligatory passage for learning while it has a sentimental quality for culture, willingness and effort. Learning combines body and mind based on biological, physiological, sociological and psychological conditions (Duman, 2009). These four concepts inherent in man show up within fundamental learning approaches. A cognitive approach considers biological and physiological constituents more important while behaviorist approaches put emphasis on the role of psychological elements in learning. On the other hand, interactive approaches draw attention to the association of innate aptitudes with social and psychological environments.

Learning takes place unconsciously until one is admitted to school when it turns into an activity consciously done by means of schooling. The difference between a mother tongue and a foreign language is evidence of this condition. A child learns sounds, words, grammar, and structures, unaware of what he is learning through the environment with which he interacts while in a non-native setting an adult learns a foreign language consciously. The child learning his mother tongue memorizes sounds and words in his mind, which he hears, internalizes and activates whenever they are needed. In foreign language learned at school by means of diverse methods and techniques, a learner is encouraged to understand certain structures. In Turkey, in a system based on grammar learning, some activities on 
phonetics and vocabulary are done, though insufficiently. Indeed, Levis (1993) stated that vocabulary plays a vital role at this age and a child assumes some fundamental and primary tasks in foreign language learning. In educational institutions, teaching vocabulary takes place by using a grammar-translation method in foreign language. It seems that vocabulary learning is an individually-completed task. The grammar-translation method alleges that the ideal way to understand the vocabulary and syntax of a foreign language is to memorize the rules of that language. Memorization of vocabulary by means of flash cards or learning vocabulary by interpreting texts as a contemporary method are some of the primary individual tasks (Bozavl1, 2014). Teaching vocabulary in foreign language by conventional methods, whether individually or collectively, may complement contemporary approaches. Sökmen (1997) told us of six different contemporary word learning methods, such as "dictionary work, word unit analysis, mnemonic devices, semantic elaboration, collocations, lexical phrases, and oral production". Each method used separate or simultaneous activates each different level of language and keeps the learner's memory continuously active. Heltai (1995) suggested that verbal translations from source to target language may be an effective method for improving vocabulary in advanced language learners, provided that certain conditions are completed (selection of appropriate texts, sufficiency of motivation level of learners, creation of an interactive, and learning environment. Unlike other activities, the advantages of verbal translation are that it is a flexible exercise, the individuals make efforts for learning language and they activate communication strategies as in mother tongue.

As Saussure (1967) indicated, words are linguistic signs or, in more technical terms, the concepts expose a two-dimensional aspect: The first one is signifier, which is the dimension that is heard or seen while the other one is signified, the concept that the sign refers to, which has an image in mind and is acquired by experience. On the one hand, there is the sound and on the other hand, the content. This study is to determine the efficiency of vocabulary teaching by homophonous English and Turkish linguistic units. In other words, it is to reveal the effect of phonetic association on vocabulary teaching. For instance, sel in Turkish means flood while "cell" in English means portable phone, but both have the same pronunciation. At what level can Turkish students of English learn vocabulary in a foreign language based on these phonetics associations? The study takes form under two hypotheses:

- By phonetic association, Turkish learners learn English vocabulary faster than those learning with other methods.

- By phonetic association, the success level of Turkish learners learning English words is greater than those learning vocabulary by other methods.

\section{Methodology}

The sample of the study consists of 6th graders studying at three secondary schools within the province whose socio-economic level is average. Since 6th graders just started to learn English systematically, they have participated in the study. It is not possible for students at this level to have knowledge of the English words with high frequency. The probability of knowing these words for the upper-class students is higher as they have seen these words the previous year. This situation influences research hypotheses. Prior to the study, it was found to what extent the students knew these words. Sixty six students, 37 girls and 29 boys, all 6th graders from 3 schools, voluntarily participated in the research. Fifteen of these students were from the first school, 32 from the second and 19 from the third.

An experimental research design was used in the study (Giroux and Tremblay, 2002). A control (rote) and an experimental group were designated. Sixty six respondents were equally divided into two groups. "English pronunciation and the meaning of English pronunciation in Turkish" sections were taken out of the vocabulary test by a phonetic association method and only the section "English words" was administered to respondents in the control group who were not given information and were unaware of the aim of the study. The participants in the experimental group were informed of vocabulary learning through a phonetic association method and the original test, "Vocabulary Test by Phonetic Association Method," was administered to the respondents. We have studied with each group for three hours for two weeks. The first week was to discover the rate of vocabulary learning of the respondents while 15 minutes in the second week was to measure the learning success permanency level of the participants. In the study conducted with the control group, 25 English words were written on the board and their Turkish meanings were found. Their pronunciations in English were available through the internet and the texts containing these words were analyzed by the respondents to enable them to learn their meanings in Turkish. Sentences were constructed with these words. A ten-minute break was given after the three-hour study. Respondents were given a test containing 25 English words and they continued to write the Turkish meanings. The respondents' accuracy was checked. In the second week, no detailed study was conducted with the respondents as in the first week. After a short interview, they were given the same test as in the first week.

The same procedure, but with different methods, was used for the experimental group. Each respondent was given the test "Vocabulary Test with Phonetic Association" at the beginning of the study. By means of English pronunciation, the 
homonymous words in Turkish were asked. In addition, the homonymous words were written on the board and first the pronunciation of the English words and then their meanings were repeated by the class.

The visual material included recalling the words such as photograph or video and were shown by means of a PC or a projector so that the content of the words was formed. For instance, when "car" in English and "kar/snow" in Turkish were pronounced, a short video including snow and car (a car going on snow) for ten to twelve seconds. Likewise, a video in which the words "sel in Turkish/flood in English" and "cell in English/hücre in Turkish" were vocalized was shown to the participants. Throughout the test, abstract concepts (gam/worry), though not many, were also introduced to the participants by means of the photos with sad man portraits and glue. This was repeated so that the images could be retained. After the three-hour study, the tests were collected and the test that contained only the English words was distributed to the participants to write the Turkish meanings, which also was completed by the control group. In the second week, after a short interview, the same test was given to the respondents.

Document analysis was used to analyze the data (Y1ldırım and Ali, 2000). By examining the texts in different sources (time magazine, daily news, as examples). The homonymous words in Turkish were found. High-frequency words in daily language were preferred in selection and the research was limited to 25 words in accordance with the design of the study. A "phonetic association vocabulary test" in which English words, mostly nouns and verbs, were vocalized and the Turkish words of these vocalizations were given, was formed. The data were interpreted by descriptive and content analysis.

\section{Results}

A word in a native language is learned in a non-native environment where the language learned is not spoken by the community by means of these methods: "meaning, written form, spoken form, grammatical characteristics, collocation, register constraints, frequency, and association". Among these learning methods are such strategies as "the learning of word pairs, teaching the underlying meaning of a word, teaching word families instead of words, teaching word parts, exploring a simple word and teaching groups of words together and cross-association". These methods and strategies may lead to successful results only through efficient and interactive use of language in classrooms (Schmitt, 2007). "Exploring a word and cross-association" is a type of vocabulary learning by an association method. Association reminds learners of a phenomenon, situation, idea or someone. In other words, it is the interaction of mind and subconsciousness. It is a fact that ideas remind themselves because there is unity, similarity or contrast between them in terms of space, time, reason and cause and effect, or psychological activities and functional relations between situations (Oğuzkan, 1974). Words are not stored in our mental lexicon as single items, but as forming clusters with related concepts. They reinforce one another's meaning so we understand words in association with others words (Jullian, 2002). The notion of "associationism" is actually as old as the speculation about mind and can be traced to Greek philosophy. It means that ideas, images and thoughts are related in such a way that the occurrence of one brings to mind another one "associated" with it (Amer, 1980).

The effect of association is evident in speaking. In dialogues, one topic leads to another in speaking. The speech of the speaker has an incentive effect on the listener as the listener does on the speaker.

It is possible to see different examples of phonetic associations as a world-wide technique. The method that Paivio and Desrochers (1981) called "keyword method," which they claimed to enable learning vocabulary faster and more retentively, they suggested that the learners find associations in their mother tongues that would remind them of the meanings and forms of the words in foreign languages. These associations act like a bridge between the languages. For example, a native speaker of french may want to learn the English word "parrot" and should make a phonetic association with a homonymous word like "Pierrot". In that case, it would be easier to make an association between "parrot and pierrot" semantically and visually (parrot is as colorful and amusing as pierrot) and learn the word "parrot" faster. Later studies found that such methods were useful and effective (Op cit. Van der linden, 2006). A native speaker of french learning English would choose homonyms between two languages as a baseline. When learning the word "cloud" in English, the word "clou/nail" would make it easier to learn that word.

The "phonetic association method vocabulary test" given in Table 1 was conducted on the experimental group and the results are included in Table 2 , below. 
Table 1. Phonetic Association Method Vocabulary Test

\begin{tabular}{|c|c|c|}
\hline $\begin{array}{c}\text { PRONOUNCIATION IN } \\
\text { ENGLISH } \\
\end{array}$ & $\begin{array}{c}\text { TURKISH MEANING OF } \\
\text { PRONUNCIATION IN ENGLISH }\end{array}$ & ENGLISH WORD \\
\hline US /ka:r/ & kar (snow) & car (noun) \\
\hline mæn /men/ US & men/men etmek (restraint) & man (noun) \\
\hline US /i:t/ & it/itmek (push) & eat (verb) \\
\hline US /di:p/ & dip (bottom) & deep (adjective) \\
\hline $\mathbf{U S} / \mathrm{d} 3^{2}: \mathrm{t} /$ & dört/four & dirt (noun) \\
\hline US /ai/ & ay(moon) or (month) & eye (noun) \\
\hline $\mathbf{U S} / \mathrm{di}_{\mathrm{I}} /$ & diş (tooth) & dish (noun) \\
\hline $\mathbf{U K} / \mathrm{f}_{\mathrm{I}} \mathrm{H} / \quad \mathbf{U S} / \mathrm{fI}_{\mathrm{I}} \mathrm{d} /$ & fiș (slip) & fish (noun) \\
\hline $\mathbf{U K} / \mathrm{bit} / \mathbf{U S} / \mathrm{bit} /$ & bit (louse) & bit (noun) \\
\hline UK /li:f/ US /li:f/ & lif (fiber) & leaf (noun) \\
\hline $\mathbf{U K} / \Lambda \mathrm{s} / \mathbf{U S} / \Lambda \mathrm{s}$ & as /asmak (hang up) & us (pronon) \\
\hline $\mathbf{U K} / \mathrm{g} \Lambda \mathrm{m} / \mathbf{U S} / \mathrm{g} \Lambda \mathrm{m}$ & gam (worry) & gum (noun) \\
\hline US /pi:s/ & pis (dirty) & peace (noun) \\
\hline $\mathbf{U S} / \mathrm{In} /$ & in (cave) & inn (noun) \\
\hline UK /'hın.i/ US /'h hn.i/ & hani (where) & honey (noun) \\
\hline UK /ko:1/ US /ka:1/ & kol (arm) & call (verb) \\
\hline $\mathbf{U K} / \mathrm{k} \int / \mathbf{U S} / \mathrm{k} \int /$ & keş (blind drunk) & cash (verb) \\
\hline $\mathbf{U S} / \mathrm{sel} /$ & sel (flood) & cell (noun) \\
\hline UK /ko:z/ US /ka:z/ & koz (trump) & cause (verb) \\
\hline $\mathbf{U K} / \mathrm{k} \Lambda \mathrm{t} / \mathbf{U S} / \mathrm{k} \Lambda \mathrm{t} /$ & kat (floor) & cut (verb) \\
\hline US /i:z/ & iz (trace) & ease (noun) \\
\hline $\mathbf{U K} / \mathrm{p} v \mathrm{t} / \mathbf{U S} / \mathrm{p} v \mathrm{t} /$ & put (idol) & put (verb) \\
\hline US /pol/ & pul (stamp) & pull (verb) \\
\hline $\mathbf{U K} / \mathrm{taI} / \mathbf{U S} / \mathrm{taI} /$ & tay (colt) & tie (verb) \\
\hline UK /ju:z/ US /ju:z/ & yüz (face) & use (verb) \\
\hline
\end{tabular}

Table 2. Experimental Group Test Results

\begin{tabular}{|c|c|c|c|c|c|c|c|c|c|}
\hline \multirow[b]{2}{*}{ 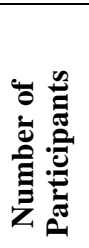 } & \multicolumn{3}{|c|}{ Pre-Test (First Week) } & \multicolumn{6}{|c|}{ Second Week } \\
\hline & $\begin{array}{c}\text { The } \\
\text { number of } \\
\text { words } \\
\text { known } \\
\text { before the } \\
\text { test }\end{array}$ & 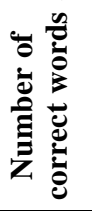 & 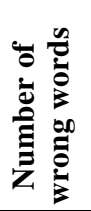 & 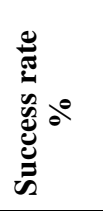 & 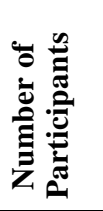 & 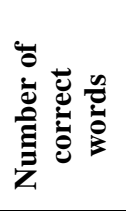 & 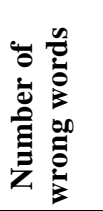 & 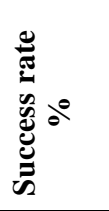 & $\begin{array}{c}\text { Success } \\
\text { Tendency }\end{array}$ \\
\hline 1 & - & 15 & 10 & 60 & 1 & 17 & 8 & 68 & \\
\hline 2 & - & 17 & 8 & 68 & 2 & 19 & 6 & 76 & \\
\hline 3 & - & 16 & 9 & 64 & 3 & 16 & 9 & 64 & \\
\hline 4 & 1 & 18 & 7 & 72 & 4 & 18 & 7 & 72 & \\
\hline 5 & - & 15 & 10 & 60 & 5 & 17 & 8 & 68 & \\
\hline 6 & - & 14 & 11 & 56 & 6 & 16 & 9 & 64 & \\
\hline 7 & - & 16 & 9 & 64 & 7 & 15 & 10 & 60 & \\
\hline 8 & - & 20 & 5 & 80 & 8 & 24 & 1 & 96 & \\
\hline 9 & 1 & 19 & 6 & 76 & 9 & 23 & 2 & 92 & \\
\hline 10 & - & 17 & 8 & 68 & 10 & 18 & 7 & 72 & \\
\hline 11 & - & 12 & 13 & 48 & 11 & 14 & 11 & 56 & \\
\hline 12 & - & 16 & 9 & 64 & 12 & 17 & 8 & 68 & \\
\hline 13 & - & 18 & 7 & 72 & 13 & 18 & 7 & 72 & \\
\hline 14 & - & 17 & 8 & 68 & 14 & 19 & 6 & 76 & \\
\hline 15 & - & 18 & 7 & 72 & 15 & 22 & 3 & 88 & \\
\hline 16 & - & 14 & 11 & 56 & 16 & 15 & 10 & 60 & \\
\hline 17 & - & 15 & 10 & 60 & 17 & 17 & 8 & 68 & \\
\hline 18 & - & 13 & 12 & 52 & 18 & 15 & 10 & 60 & \\
\hline 19 & - & 16 & 9 & 64 & 19 & 17 & 8 & 68 & \\
\hline 20 & 1 & 18 & 7 & 72 & 20 & 18 & 7 & 72 & \\
\hline 21 & - & 15 & 10 & 60 & 21 & 17 & 8 & 68 & \\
\hline 22 & - & 17 & 8 & 68 & 22 & 18 & 7 & 72 & \\
\hline 23 & - & 15 & 10 & 60 & 23 & 16 & 9 & 64 & \\
\hline 24 & - & 14 & 11 & 56 & 24 & 16 & 9 & 64 & \\
\hline 25 & - & 12 & 13 & 48 & 25 & 13 & 12 & 52 & \\
\hline 26 & - & 16 & 9 & 64 & 26 & 15 & 10 & 60 & \\
\hline 27 & - & 18 & 7 & 72 & 27 & 22 & 3 & 88 & \\
\hline 28 & - & 15 & 10 & 60 & 28 & 17 & 8 & 68 & \\
\hline 29 & - & 17 & 8 & 68 & 29 & 20 & 5 & 80 & \\
\hline 30 & - & 16 & 9 & 64 & 30 & 16 & 9 & 64 & \\
\hline 31 & - & 14 & 11 & 56 & 31 & 15 & 10 & 60 & \\
\hline 32 & - & 17 & 8 & 68 & 32 & 18 & 7 & 72 & \\
\hline 33 & - & 17 & 8 & 68 & 33 & 20 & 5 & 80 & \\
\hline
\end{tabular}


The results of the test conducted on the experimental group were interesting. The first week, the number of correct words ranged between 12 and 20 and the rate of success was between $48 \%$ and $80 \%$. In the second week, the range was between 13 and 24 and the success rate was between $52 \%$ and $96 \%$. Twenty-six respondents increased their rate of success, two of them creased in performance, and five were unchanged, and 5 respondents' performances were unchanged. The success in the second week is an indicator of the advantage of this method, which distinguishes it from traditional learning methods because the words become permanent and prevents forgetting. In a non-native environment, forgetting words is commonplace when learning a foreign language.

The "control group vocabulary test" that appears Table 3 was conducted on the control group and their results appear in Table 4, below.

Table 3. Control Group Vocabulary Test

\begin{tabular}{cc}
\hline & ENGLISH WORDS \\
\hline car (noun) & inn (noun) \\
man (noun) & call (verb) \\
eat (verb) & cash (verb) \\
deep (adjective) & cell (noun) \\
dirt (noun) & cause (verb) \\
eye (noun) & cut (verb) \\
dish (noun) & ease (noun) \\
fish (noun) & put (verb) \\
bit (noun) & pull (verb) \\
leaf (noun) & tie (verb) \\
us (pronon) & use (verb) \\
gum (noun) & inn (noun) \\
peace (noun) & honey (noun) \\
\hline
\end{tabular}

Table 4.Control Group Test Results

\begin{tabular}{|c|c|c|c|c|c|c|c|c|c|}
\hline 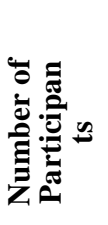 & $\begin{array}{l}\text { Pre-' } \\
\text { The } \\
\text { number } \\
\text { of words } \\
\text { known } \\
\text { before } \\
\text { the test }\end{array}$ & 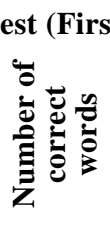 & 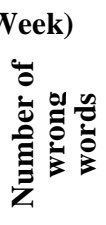 & 造 & 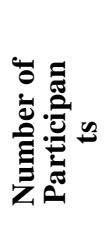 & 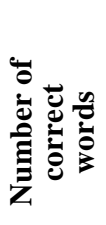 & 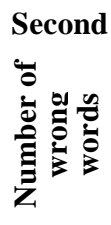 & 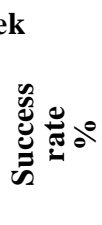 & $\begin{array}{c}\text { Success } \\
\text { Tendency }\end{array}$ \\
\hline $\mathbf{1}$ & - & 7 & 18 & 28 & 1 & 6 & 19 & 24 & \\
\hline 2 & - & 6 & 19 & 24 & 2 & 6 & 19 & 24 & \\
\hline 3 & - & 5 & 20 & 20 & 3 & 6 & 19 & 24 & \\
\hline 4 & - & 8 & 17 & 32 & 4 & 7 & 18 & 28 & \\
\hline 5 & - & 7 & 18 & 28 & 5 & 7 & 18 & 28 & \\
\hline 6 & - & 6 & 19 & 24 & 6 & 5 & 19 & 20 & \\
\hline 7 & - & 10 & 15 & 40 & 7 & 8 & 17 & 32 & \\
\hline 8 & 1 & 15 & 10 & 60 & 8 & 12 & 13 & 48 & \\
\hline 9 & - & 7 & 18 & 28 & 9 & 6 & 19 & 24 & \\
\hline 10 & - & 6 & 19 & 24 & 10 & 4 & 21 & 32 & \\
\hline 11 & - & 5 & 20 & 20 & 11 & 5 & 20 & 20 & \\
\hline 12 & - & 5 & 20 & 20 & 12 & 6 & 19 & 24 & \\
\hline 13 & - & 9 & 16 & 36 & 13 & 8 & 17 & 32 & \\
\hline 14 & - & 10 & 15 & 40 & 14 & 9 & 16 & 36 & \\
\hline 15 & - & 6 & 19 & 24 & 15 & 5 & 20 & 20 & \\
\hline 16 & - & 6 & 19 & 24 & 16 & 5 & 20 & 20 & \\
\hline 17 & - & 7 & 18 & 28 & 17 & 7 & 18 & 28 & \\
\hline 18 & - & 5 & 20 & 20 & 18 & 5 & 20 & 20 & \\
\hline 19 & - & 11 & 14 & 44 & 19 & 10 & 15 & 40 & \\
\hline 20 & - & 12 & 13 & 48 & 20 & 9 & 16 & 36 & \\
\hline 21 & - & 7 & 18 & 28 & 21 & 7 & 18 & 28 & \\
\hline 22 & - & 6 & 19 & 24 & 22 & 4 & 21 & 16 & \\
\hline 23 & 1 & 7 & 18 & 28 & 23 & 5 & 20 & 20 & \\
\hline 24 & - & 4 & 21 & 16 & 24 & 4 & 21 & 16 & \\
\hline 25 & - & 8 & 17 & 32 & 25 & 5 & 20 & 20 & \\
\hline 26 & - & 9 & 16 & 36 & 26 & 7 & 18 & 28 & \\
\hline 27 & - & 5 & 20 & 20 & 27 & 4 & 21 & 16 & \\
\hline 28 & - & 4 & 21 & 16 & 28 & 4 & 21 & 16 & \\
\hline 29 & - & 6 & 19 & 24 & 29 & 5 & 20 & 20 & \\
\hline 30 & - & 7 & 18 & 28 & 30 & 3 & 22 & 12 & \\
\hline 31 & - & 4 & 21 & 16 & 31 & 5 & 20 & 20 & \\
\hline 32 & - & 5 & 20 & 20 & 32 & 5 & 20 & 20 & \\
\hline 33 & - & 6 & 19 & 24 & 33 & 4 & 21 & 16 & \\
\hline
\end{tabular}


The number of correct words known had a range between 4 and 15 and their rate of success ranged between $16 \%$ and $60 \%$, according to the test in Table 3 conducted on the control group in the first week. In the second week, the number of words guessed correctly ranged from three to 12 while minimum rates of success ranged from $12 \%$ to $48 \%$. Compared to the first week, a decrease was discovered in the second week in both the number of correct words guessed and the rate of success. The rate of success of most participants decreased. In the second week, the rate of success of 20 respondents decreased, 9 participants' scores were unchanged, and four increased their rates of success.

\section{Discussion and Conclusion}

The rate of success of the group on which vocabulary learning by a phonetic association method was conducted is different from traditional methods of learning vocabulary more positively in terms of both rate of learning and retention level. In the study conducted during the first week, aiming to determine the rate of learning, the rate of the control group success ranged from $16 \%$ to $60 \%$ while the experimental group's success rate ranged from $48 \%$ to $80 \%$.

In the study conducted in the second week to determine the permanency of learning success, the rate of success of the control group ranged from $12 \%$ to $52 \%$ while that of the experimental group had a range between $52 \%$ and $96 \%$. These results suggest that those learning words in foreign languages by phonetic association learn faster and more retentively. One of the advantages is certainly the retention of what is learned rather than the rate of learning.

The success in vocabulary learning by this method could be related to the activation of different sense organs of the learners at the same time. The greater the number of sense organs are in learning, the better and more retentive the learning is. Learners can remember $20 \%$ of what they see and $50 \%$ of what they hear (Koşar et al, 2004). The respondents have heard the pronunciation of the words and have been able to study the relation between signifier and signified in their mind by seeing the images. In other words, although the participants of both groups repeat the words in the tests several times in periods other than during the research. The fact that the participants of the experimental group are more successful in recall is due to the symbolization of the words they learn.

We repeat a name or a number because we want to remember it later; we can create an image and imagine mnemonics (Terry, 2007). When words, if possible, are learned with their pronunciation and images, they can be learned more easily because the words have a verbal and a visual form (Van der linden, 2006). In this way, the participants have related phonetic a dimension with a visual dimension by means of supportive techniques (video, images, as examples) and increased the rate of success.

Some researchers suggest that an association method with a cognitive quality is important in vocabulary learning and has yielded interesting results. Association techniques can be valuable because they allow learners to have a deeper learning process, and more combinations to assist that deeper process (Shen, 2003). Cohen and Aphek (1980) stated that those using the association method learn memorizing words faster and are more successful in learning when compared to those not using that method. Anjomafrouz and Tajalli (2012), examining the rate of success of Iranian students in learning words by an association method, found that using mnemonic associations led to significantly better performance of adult students when a comparison was made with respect to an external control group (rote group) and better performance of both adult and adolescent groups when a comparison was made with respect to an internal control group (when students used no associations in the mnemonic group).

Association takes place not only in mother tongue acquisition, but also in making sense of social life. One of the popular language acquisition approaches is that the meanings of the words are learned by associative relations with the objects to which they refer. Mother says shoe by pointing at the shoe, child points at the child and says stove by saying whew. Indeed, the child learns shoe, child and fire concepts by associations of shoe, self and stove (Chao, 1970). Cloudy weather signals rain, the smoke far out, fire and snow coldness.

Twenty-five English words, mostly nouns and verbs in the table were found based on the homonyms in Turkish. It is also possible to find words in the same way with different quality. In the sentence, other predictive and nominal English words have homonyms with Turkish words such as "in/in(cave), more/mor(a colour-purple), is/iz(mark), by/bay(sir), all/ol(to be in singular form), at/et (meat), on/on(teen), much/maç/(match), as/ez(crush imperative form), where/ver (give third person in imperative form), who/hu (exclamation in Turkish), why/vay(exclamation of surprise)" and love/lav(cinder), meat/mit(myth), hot/hat(line), peach/piç(an expression of insult in Turkish like bastard), and leaf/lif(fibre), which have function as prepositions, adverbs, pronouns, and adjectives.

In addition, based on commercial and technological interaction, it is possible to mention the presence of the words with high frequency, which are semantically the same as in speaking Turkish. "Air bag, large, small, medium, best-seller, bodyguard, center, check-up, driver, exit, hard disc, show, showman, finish, show room, level, security, printer, smart, meeting, data, online, part time, full time, full, download, save" are some of these words. Adding a suffix "etmek" to the end of the verbs as "full, save, download, check", words are produced half Turkish and half English as in the example 
"fullemek, save etmek, check etmek, download etmek". These words, "full, save, check, download" are regarded as authenticated and are used in daily English with their meanings. In accordance with phonetic association, words used at this design could be regarded as enough to function in communication with English as a baseline.

It is not possible to claim that a phonetic association method is a method to be used for teaching vocabulary in a foreign language on its own. It should, rather, be used as a supportive technique to other methods. These methods can be used independently or simultaneously at beginner, elementary and intermediate level. Indeed, some association types could be consulted at an advanced level.

\section{References}

Amer, A. A. M. (1980). A comparative study of English and Egyptian Word associations and their implications fort he teaching of English to Egyptian learners. London: University Institute of Education.

Anjomafrouz, F., \& Tajalli, G. (2012). Effects of Using Mnemonic Associations on Vocabulary Recall of Iranian EFL Learners over time. International Journal of English Linguistics; 2(4). http://dx.doi.org/10.5539/ijel.v2n4p101

Bozavlı, E. (2014). Yabancı Dil Dersinde Kelime Öğretiminde Görsel İşitsel Materyallerin Etkinliğinin Değerlendirilmesi (Tv 5 Monde $/ 7$ Jours Sur La Planete Modeli). Ankara: Turkish Studies, 9(12). https :doi.org/10.7827.9566

Chao, Y. R. (1970). Langage et Systemes Symboliques. (Çev: Calvet, J.L) Paris: Payot.

Cohen, A., \& Aphek, E. (1980). Retetion of second-language vocabulary over time: investigating the role of mnemonic associations. Great Britain: System, 8, 221-235. https://doi.org/10.1016/0346-251X(80)90004-4

Duman, B. (2009). Neden Beyin Temelli Öğrenme. Ankara: Pegem Akademi Yayıncılık.

Giordan, A. (1998). Apprendre. Paris: Editions Belin.

Giroux, S., \& Tremblay, G. (2002). Méthodologie des sciences humaines, la recherché en action. Québec: Erpi.

Heltai, P. (1995). Teaching vocabulary by oral translation. Oxford University Press: ELT Journal, 49/2.

Jullian, P. (2002). Word associations: a resource to raise awareness about semantic relations, 7, 519-529.

Koşar, E., Yüksel, S., Özkılıç, R., Avcı, U., İmer, G., \& Çiğgem, H. (2004). Öğretim Teknolojileri ve Materyal Geliştirme. Ankara: Pegem A Yayıncılık.

Levis, M. (1993). The Lexical Approach. England: Language Teaching Publications.

Oğuzkan, F. (1974). Eğitim Terimleri Sözlüğ̈̈, Ankara: TDK Yayınları.

Özer, A. (2005). Etkin Öğrenmede Yeni Arayışlar: İşbirliğine Dayalı Öğrenme ve Buluş Yoluyla Öğrenme. Ankara: Bilig, 35, 105-131.

Saussure, F. (1967). Cours de linguistique générale. Paris : Editions Payot.

Schmitt, N. (2007). Current trends in vocabulary learning and teaching. Cummins, J. and Davison, C. (eds.), The International Handbook of English Language Teaching, 2, Springer.

Shen, W. W. (2003). Current trends of vocabulary teaching and learning strategies for EFL setting. Taiwan: Feng Chia Journal of Humanities and social sciences, 7, 187-224.

Sökmen, A. J. (1997). Currents trends in teaching second language vocabulary. Schmitt, N. and M. McCarthy. Vocabulary: Description, Acquisition and Pedagogy. Cambridge: Cambridge Universty Press.

Terry, W. S. (2007). Learning \& Memory, Basic Principles, Processes and Procedures. (Çev: Cangöz, B. 2013). Ankara: Anı Yayincilik.

Van der Linden, E. (2006). Lexique mental et apprentissage des mots. Amsterdam: Revue française de linguistique appliquée, XI, 33-44.

Yıldırım, A., \& Şimşek, H. (2000). Sosyal Bilimlerde Nitel Araştırma Yöntemleri. Ankara: Seçkin Yayıncılık.

\section{Copyrights}

Copyright for this article is retained by the author(s), with first publication rights granted to the journal.

This is an open-access article distributed under the terms and conditions of the Creative Commons Attribution license which permits unrestricted use, distribution, and reproduction in any medium, provided the original work is properly cited. 